\title{
PATHOGENESIS OF THROMBOCYTOPENIA IN ACUTE CLASSICAL SWINE FEVER
}

\author{
N. L. CALDERON ${ }^{1}$, T. I. FORTOUL ${ }^{2}$, L. H. PAASCH ${ }^{3}$, J. BOUDA ${ }^{4}$ \\ ${ }^{1.3}$ Department of Avian Production. Faculty of Veterinary Medicine and Animal Science, ${ }^{2}$ Department of Cell \\ Biology, Faculty of Medicine, ${ }^{4}$ Department of Clinical Diagnosis, Faculty of Veterinary Medicine and Animal \\ Science, National Autonomous University of Mexico, 04510 México City
}

Received March 11, 1998

Accepted June 5, 1998

\begin{abstract}
Calderón N. L., T. I. Fortoul, L. H. Paasch, J. Bouda: Pathogenesis of Thrombocytopenia in Acute Classical Swine Fever. Acta vet. Brno 1998, 67: 115-119.

Ultrastructural evaluations of bone marrow in 16 pigs experimentally infected with the classical swine fever virus and 4 control pigs were performed, in order to determine if classical swine fever virus causes direct damage on platelets or its precursors. A progressive degeneration of megakaryocytes was detected starting at day 1 post infection. The degenerative process ended with necrosis of megakaryocytes. Platelet budding did not present the expected cytoplasmic demarcation and emerging platelets lacked the normal cytoplasmic structure. Since classical swine fever virus particles were observed in degenerated megakaryocytes, it was concluded that megakaryocyte damage caused by classical swine fever virus is responsible for the thrombocytopenia detected in early stages of this disease.
\end{abstract}

Classical swine fever, electron microscopy, megakaryocyte, pathogenesis, pigs, thrombocytopenia

Classical swine fever (CSF) is a highly contagious viral disease in swine. It is characterized by an extensive endothelial damage which may vary from swelling of endothelial cells with thickening of capillary walls to fibrinoid necrosis of capillaries (Dunne 1973; Robinson and Gran Maxie 1993; Terpstra 1991). Associated to endothelial damage, an extensive formation of microthrombi in arterioles and capillaries is present (Cotran 1994). The aforementioned multiple thrombosis has been discussed by several authors (Dahle and Liess 1992; Heene et al. 1971; Hoffmann et al. 1971a) as disseminated intravascular coagulation (DIC). Many viral diseases such as infectious canine hepatitis, African swine fever, bluetongue, epizootic hemorrhagic disease of deer, and others may induce DIC (Robinson and Gran Maxie 1993). It is considered that in acute CSF, several disorders of the coagulation system are present, and that thrombocytopenia is part of a consumptive coagulopathy (Traut we in 1988). However, in CSF, the platelet count is often depressed and it is out of proportion to degree of the severity of coagulation abnormalities (Calderón et al. 1997). This depression presumably reflects the limited production capacity of the megakaryocyte. Thrombocytopenia, therefore, may result from processes other than the utilization of platelets in thrombotic lesions (Bithell 1993). It is also important to emphasize that in acute CSF, thrombocytopenia may be detected at early stages, before disseminated thrombosis takes place (Calderón et al.1997). Futhermore, CSF virus is frequently recovered from bone marrow in natural infection (Dunne 1963; Heene et al. 1971; Hoffmann et al. 1971b). The aforementioned data suggest that platelet 
precursors in bone marrow could be affected by CSF virus causing thrombocytopenia. Early and progressive significant reduction in platelet counts characteristic in CSF is consistent with the findings of sequential bone marrow histological evaluations which show a progressive degeneration of megakaryocytes (Calderón et al. 1997). In this respect, it is of comparative interest, that in African swine fever about $10 \%$ of megakaryocytes were infected with African swine fever virus which was demonstrated by immunofluorescence microscopy (Edwards 1985). On the other hand several viral infections in humans such as varicella, hepatitis and rubeola are frequently associated with a selective insufficient megakaryocyte pool (Bick 1988; Jobin 1995). Thus, the aim of the present study was to determine if CSF virus destruction of megakaryocytes in the bone marrow is an important pathogenic factor of thrombocytopenia in this disease.

\section{Materials and Methods}

The study was performed in 20 crossbred, six to eight week old pigs obtained from farms regarded as free of classical swine fever (CSF). In every case absence of antibodies against CSF virus was verified by the seroneutralizing test. Sixteen pigs were infected by a single intramuscular dose of $10^{6}$ tissue culture infected dose $50 \%\left(\mathrm{TCID}_{50}\right), \mathrm{CSF}$ virus (Ames Iowa strain). The remaining 4 pigs were used as controls. Clinical sings and rectal body temperature were recorded daily during the experiment. The procedures conducted with experimental and control pigs were in agreement with the regulations established for animal welfare in the College of Veterinary Medicine of the National Autonomous University of Mexico.

\section{Ultrastructural studies}

Two infected pigs were euthanatized daily during eight consecutive days, by an overdose anesthesia (Anestesal). Immediately after euthanasia, bone marrow samples were taken from the proximal femur for histological and electron microscopy studies. Samples were fixed in $2.5 \%$ glutaraldehyde in $0.1 \mathrm{M}$ sodium cacodylate buffer, $\mathrm{pH}$ $7.4(470 \mathrm{mosmol} / \mathrm{L})$ and cut in 3 to $5 \mathrm{~mm}$ pieces, postfixed in $1 \%$ osmium tetroxide for two hours, dehydrated in alcohol series and embedded in Epon 812 . Semithin $90 \mathrm{~nm}$ thick sections were stained with $1 \%$ aqueous toluidine blue solution and observed with the light microscope to select suitable blocks containing megacaryocytes. Thin 60 $\mathrm{nm}$ thick sections were contrasted with uranyl acetate and Reynold's lead citrate. Sections were observed and photographed in a transmission electron microscope Zeiss EM 109.

\section{Results}

The clinical signs detected in the infected pigs were fever, diarrhea, incoordination and skin erythema.

Light microscopy observations of semithin sections revealed cell depletion and marked megakaryocyte degeneration.

On day 1 post infection, electron microscopy observations revealed dilatation of endoplasmic vesicles and tubules of most megakaryocytes. The transition from the intermediate to the marginal zone was abrupt in the same cells and platelet budding did not present the normal cytoplasmatic demarcation. Emerging platelets lacked the normal cytoplasmic granules (Plate VII., Fig. 1).

In some dilated vesicles of megakaryocytes, 40 to $50 \mathrm{~nm}$ electron-dense, spherical structures were detected (Plate VIII., Fig. 2).

On days 2 and 3 post infection dilated vesicles containing spherical electron-dense structures were more abundant and demarcation tubules were inconspicuous. Dense and clear granules were depleted and glycogen was more abundant in most megakaryocytes.

On days 4 to 6 post infection, megakaryocytes were reduced in number, and therefore, difficult to find in thin sections. In the remaining megakaryocytes many spherical electron-dense structures were observed in dilated vesicles and demarcation tubules 
remained only as ghost structures. Glycogen content was very conspicuous and was aggregated in focal cytoplasmic areas (Plate IX., Fig. 3). Cytoplasmic megakaryocyte demarcation was lost.

Finally on days 7 to 8 post infection megakaryocytes were necrotic.

\section{Discussion}

The clinical signs detected in the infected pigs of the present study were consistent with those described in the literature for acute classical swine fever (CSF) (Dahle and Liess 1992; Dunne 1973; Trautwein 1988).

In a previous extensive study, it was found that in the course of experimental CSF multiple defects of coagulation systems could be detected, and since hemorrhages and disseminated thrombosis were simultaneously present, the authors suggested a consumptive coagulopathy as a pathogenic mechanism of thrombocytopenia (Heene et al. 1971). The latter probably refers only to final stages of the disease. In this regard, it is important to consider studies conducted during the acute phase of CSF where no significant changes were determined in the parameters of intrinsic and extrinsic coagulation pathways (Calderón et al. 1997).

On the other hand, in other previous work (Dunne 1963; Hoffmann 1971b) the course of CSF has been found to be similar with early and progressive significant reduction in platelet counts.

A study of sequential bone marrow histological evaluations in experimental CSF revealed an early and progressive degeneration of megakaryocytes (Calderón et al. 1997). The aforementioned findings were consistent with the light and electron microscopy observations of the present study which demonstrate a progressive degeneration of megakaryocytes detected as early as on the first day post infection with the electron microscope.

A very significant finding in our present study was the observation of irregular spherical electron-dense particles which were present from as early as the first day of infection in cytoplasmic vesicles of megakaryocytes.

Previous studies conducted to visualize the CSF virus particle by electron microscopy, reported the viral particles as irregular spheres with an electron-dense core surrounded by less electron dense thin outer coat with a mean size of about $45 \mathrm{~nm}$ (Enzmann and Weiland 1978; Horzinek et al. 1967; Ritchie and Fernelius 1968; Scherrer et al. 1970). Particles observed in the present study were identical with the morphology and size of CSF viral particles previously described.

Furthermore, in electron microscopy observations of experimental CSF infection in tissue culture cells, the viral particles were reported as present in the interior of the Golgi apparatus and other type of cytoplasmic vesicles and vacuoles (Scherrer et al. 1970). In our study particles were associated with dilated vesicles and tubules of megakaryocytes.

In normal megakaryocytes, the major part of the cytoplasm is characterized by the formation of platelet demarcation membranes which develop from demarcation vesicles and tubules. Demarcation membranes form the plasma membrane of platelet (Zucker Franklin 1970). In this respect, it is important to emphasize that in our study, infected megakaryocytes exhibited a severely damaged system of endoplasmic reticulum characterized by conspicuous dilation on the first day post infection to complete degeneration of the tubule system on day 4 post infection. It is highly probable that the previously described damage of the megakaryocyte is the cause of thrombocytopenia detected in early stages of this disease. 


\section{Patogeneze trombocytopenie při klasickém moru prasat}

Vyhodnocení ultrastruktury kostní dřeně bylo provedeno u 16 prasat experimentálně infikovaných virem klasického moru prasat a u 4 jedinců kontrolních. Cílem práce bylo zjistit, zda virus moru prasat způsobuje přímé poškození trombocytů nebo jejich vývojových stadií. Výrazná degenerace megakaryocytů byla zjištěna 1. den po infekci. Degenerativní proces končil nekrózou megakaryocytů. V nevyvinutých trombocytech nebyla pozorována očekávaná cytoplasmatická demarkace a $\mathrm{v}$ nově vytvořených trombocytech chyběla normální cytoplasmatická struktura. Na základě virových partikulí klasického moru prasat, zjištěných v degenerovaných megakaryocytech jsme usoudili, že jejich poškození způsobené tímto virem je přičinou trombocytopénie zjištěné $v$ časné fázi onemocnění.

\section{Acknowledgements}

We thank to Ms. S. Antuna and Mr. A. Rondan for their electron microscopy technical assistance. and to Mr. F. Pasos for his valuable support with the illustrations. Dr. Calderón is grateful to The National Council of Science and Technology of Mexico for the support of her doctoral studies. This investigation was supported in part by the Graduate School of The National Autonomous University of Mexico.

\section{References}

BICK, R. L. 1988: Disseminated intravascular coagulation and related syndromes: A clinical review. Semin. Thromb. Hemostasis. 14: 299-338

BITHELL. T. L. 1993: Acquired coagulation disorders. In: Wintrobe's Clinical Hemathology, Vol. 2. 9th ed. Philadelphia: Lea and Febiger. pp. 1473-1510

CALDERÓN, N. L., PAASCH, L. H., BOUDA, J. 1997b: Haematological and histological bone marrow findings in experimental classical swine fever. Acta vet. Brno 66: 171-176

COTRAN, R. S., KUMAR, V., ROBBINS, S. L. 1994: Diseases of red cells and bleeding disorders. In: Pathologic Basis of Disease, 5th ed. Philadelphia: W.B. Saunders Company pp. 623-627

DAHLE, J., LIESS, B. 1992: A review on classical swine fever infections in pigs: Epizootiology, clinical disease and pathology. Comp. Immun. Microbiol. infect. Dis. 15: 203-211

DEBBIE. J. G., ABELSETH, M. K. 1971: Pathogenesis of epizootic hemorrhagic diseases. I. Blood coagulation during viral infection. J. Infect. Dis. 124: 217-222

DUNNE, H. W. 1963: Field and laboratory diagnosis of hog cholera. Vet. Med. 53: 222-239

DUNNE, H. W. 1973: Hog cholera (Eropean swine fever). Adv. Vet. Med. 17: 315-359

EDWARDS, J. F., DODDS, W. J., SLAUSON, D. O. 1985: Megakaryocytic infection and thrombocytopenia in African swine fever. Vet. Pathol. 22: 171-176

ENZMANN, P-J., WEILAND, F. 1978: Structural similarities of hog chlolera virus with togaviruses. Arch. Virol. 57: 339-348

HEENE, D., HOFFMANN-FEZER, G., HOFFMANN, R., WEISS, E., MÜLLER-BERGHAUS, G., LASCH, H. G. 1971: Gerinnungsstörungen bei akuter Schweinepest. Beitr. Pathol. Bd. 144: 259-271

HOFFMANN, R., HOFFMANN-FEZER, G., KIMETO, B., WEISS, E. 1971a: Mikrothromben als morphologischer Ausdruck einer Verbrauchskoagulopathie bei akuter Schweinepest. Zbl. Vet. Med. B 18: 710-718

HOFFMANN, R., HOFFMANN-FEZER, G., WEISS, E. 1971b: Knochenmar-ksveränderungen bei akuter Schweinepest mit besonderer Berücksichtigung der thrombopoetischen Zellen. Berl. Münch. Tierärztl. Wschr. 84: $301-305$

HORZINEK, M., RECKZKO, E., PETZOLDT, K. 1967: On the morphology of hog cholera virus. Arch. ges. Virusforsch. 21: $475-478$

JOBIN, F. 1995: Les thrombopénies. In: L'Hémostase. Les Presses de L'Université Laval, Québec, Canada. pp. 229-264

RITCHIE, A. E., FERNELIUS, A. L. 1968: Direct immuno-electron microscopy and some morphological features of Hog Cholera virus. Arch. ges. Virusforsch. 23: 292-298

ROBINSON, W. F., GRANT MAXIE, M. 1993: The cardiovascular system. In: Pathology of domestic animals, Vol. 3. 4th ed. (K.V.F. Jubb, P.C. Kennedy and N. Palmer, eds.), Academic Press, Inc. pp. 62-64 
SCHERRER, R., AYNAUD, J-M., COHEN, J., BIC, E. 1970: Étude au microscope électronique du virus de la peste porcine classique (hog cholera) dans des coupes ultra-fines des cellules infectées in vitro. C R Acad. Sc. Paris 271: 620-623

TERPSTRA, C. 1991: Hog cholera: An update of present knowledge. Br. Vet. J. 147: 397-406

TRAUTWEIN, G. 1988: Pathology and pathogenesis of the diseases. In: Classical swine fever and related infections (B. Liess, ed.), Boston: Martinus Nijhoff Nordrecht. pp. 28-54

ZUCKER-FRANKLIN, D. 1970: The ultrastructure of megakaryocytes and platelets. In: Regulation of Hematopoiesis, ed. Gordon AS, vol. 2. Appleton Century Crofts, New York. pp. 1533-1583 
Plate VII.

Calderón N. L. et al.: Pathogenesis... pp. 115-119.

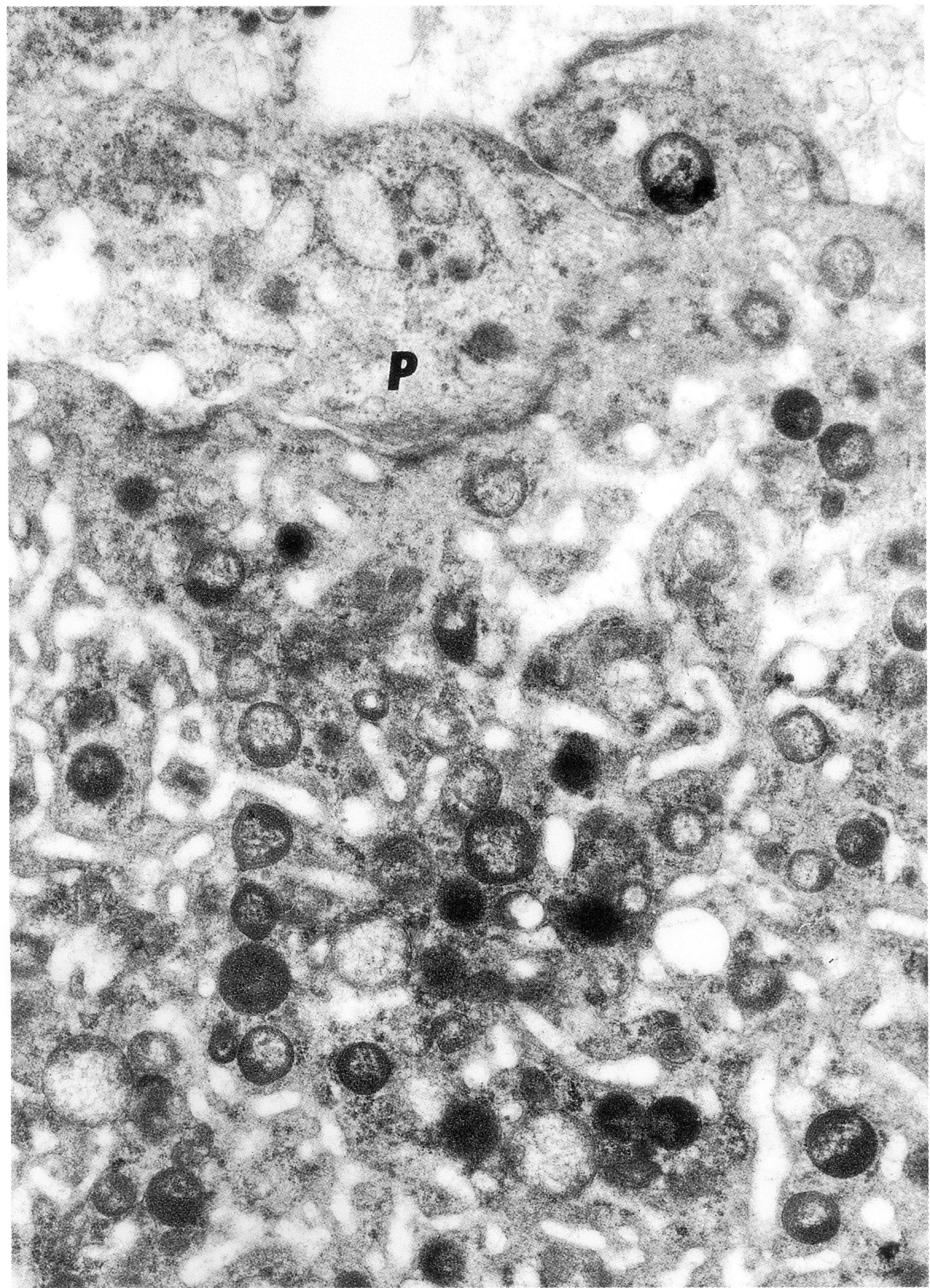

Fig. 1. Electron micrograph. Bone marrow. Infected pig, day 1 post infection. Platelet at right upper corner (P), with poorly defined granules and cytoplasmic membrane. $\times 17,600$. 


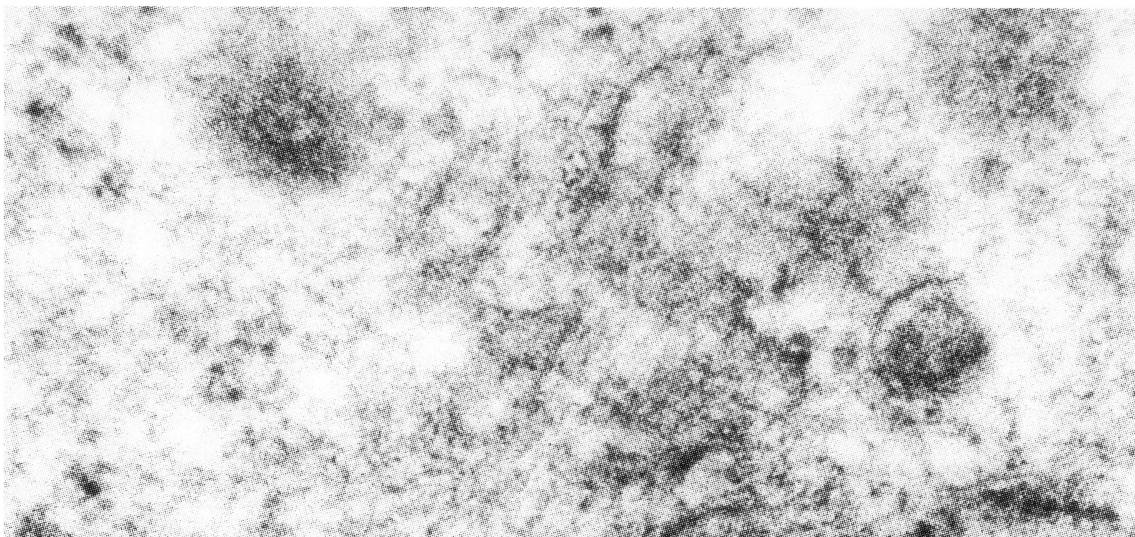

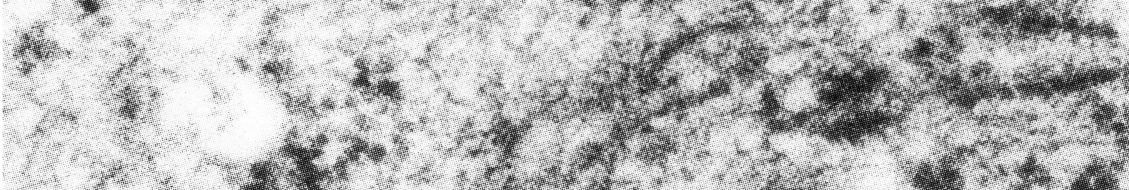

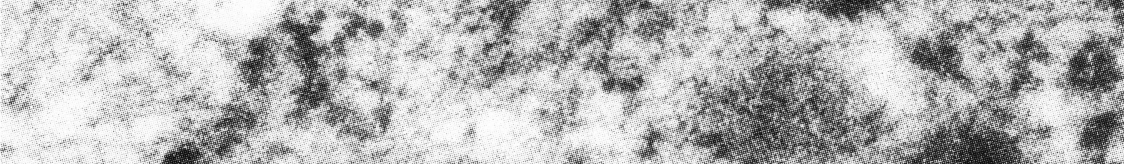

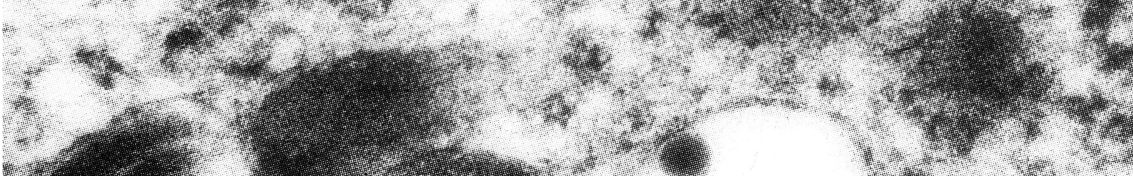

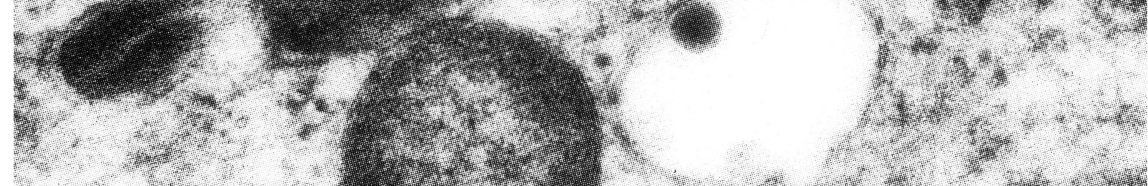

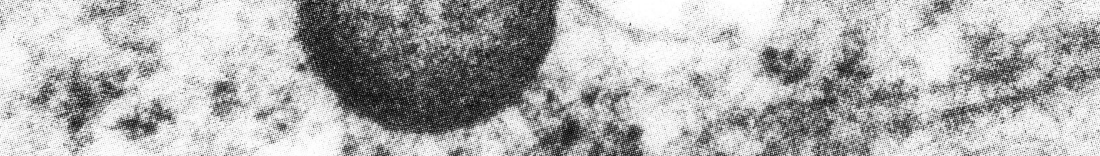

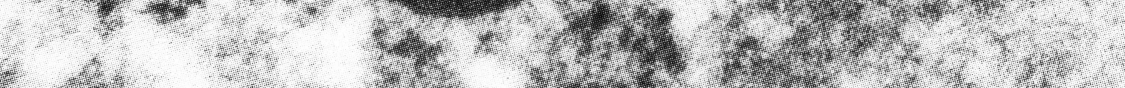

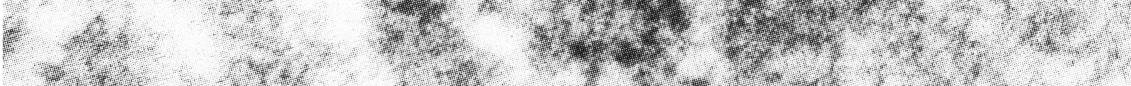

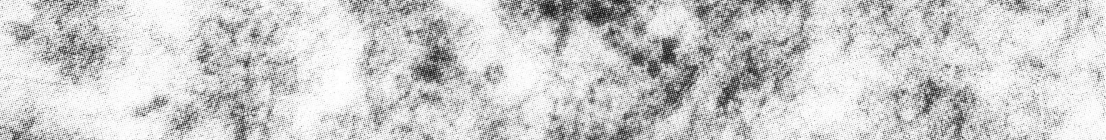

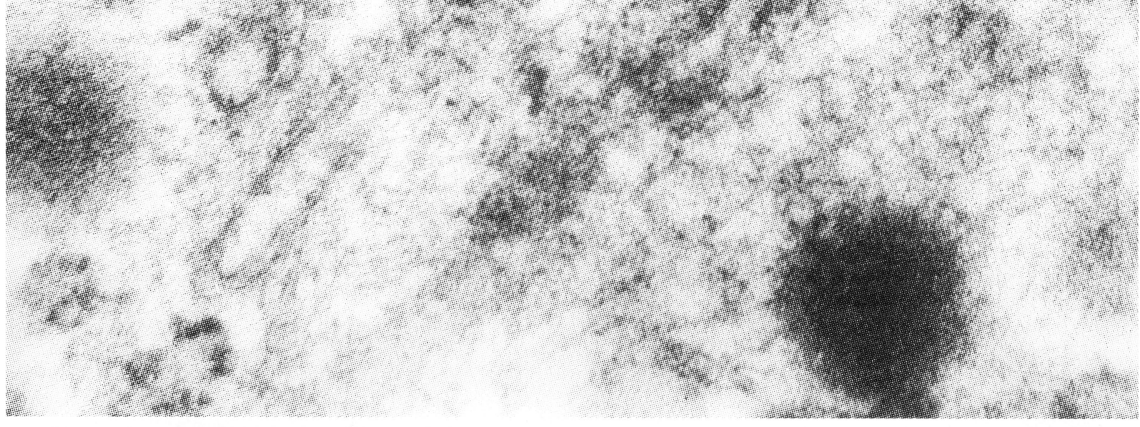




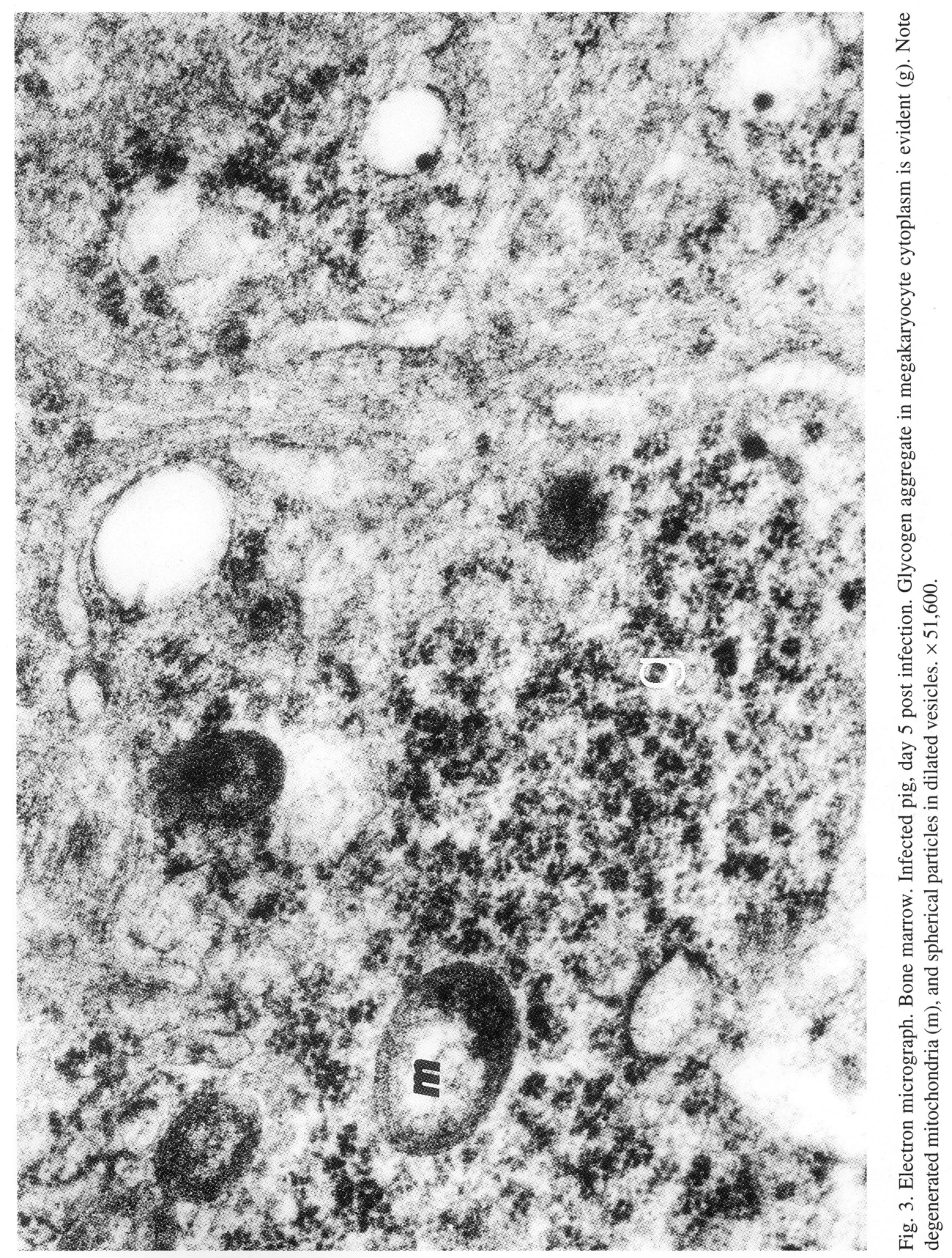

